\title{
Clima Institucional e Transferência Positiva de Conhecimentos, habilidade e Atitudes
}

seconcispP/OSS

Autores: COSTA, Roberta da Silva Costa; CANDAL, Anne Elise; LOPES, Flavia Freitas de Paula.

\section{Introdução}

As instituições de saúde investe grandes quantias em ações formais de treinamento e desenvolvimento (T\&D], com a intenção de que um grande número de funcionários transfira positivamente os conhecimentos, habilidades e atitudes [CHA] a qual foram treinadas para o ambiente de trabalho. A transferência de aprendizagem é o indílicador mais utilizado em pesquisas de T\&D para verificar a aplicação de CHA no trabalho. A influência do clima institucional tem forte relaçăa com a eficácia e transferência dos CHA.

\section{Objetivo}

Correlacionar à efetividade dos treinamentos (Aplicabilidade prática dos CHA] com o clima institucional.

\section{Método}

O Hospital Regional de Cotia (HRC) realizou a primeira pesquisa de clima institucional no ano de 2016 com a participação 271 colaboradores obtendo um índice. A efetividade dos treinamentos no HRC é medida trimestralmente de acordo com os indicadores de processo e assistências relacionados a cada treinamento. No primeiro ano da pesquisa de clima, 73\% dos treinamentos institucionais eram efetivos.

Embora o índice tenha sido satisfatório, várias ações relacionadas a T\&D foram tomadas para que a satisfação dos colaboradores aumentasse.

Em 2018 foi realizada uma nova pesquisa com a participação de 415 colaboradores com um índice de 78,5\%. Embora o índice não tenha tido um aumento significativo, ele representa mais fidedignamente o clima institucional, pois teve uma participação mais expressiva. Porém os índices relacionados a T\&D aumentaram significativamente (Gráfico I], o que impactou diretamente na efetividade dos treinamentos institucionais que passou para 83\% de treinamentos efetivos, ou seja, houve transferência positiva das CHA.

\section{Gráfico I}

\section{Pesquisa de Clima: Experiencia Profissional}

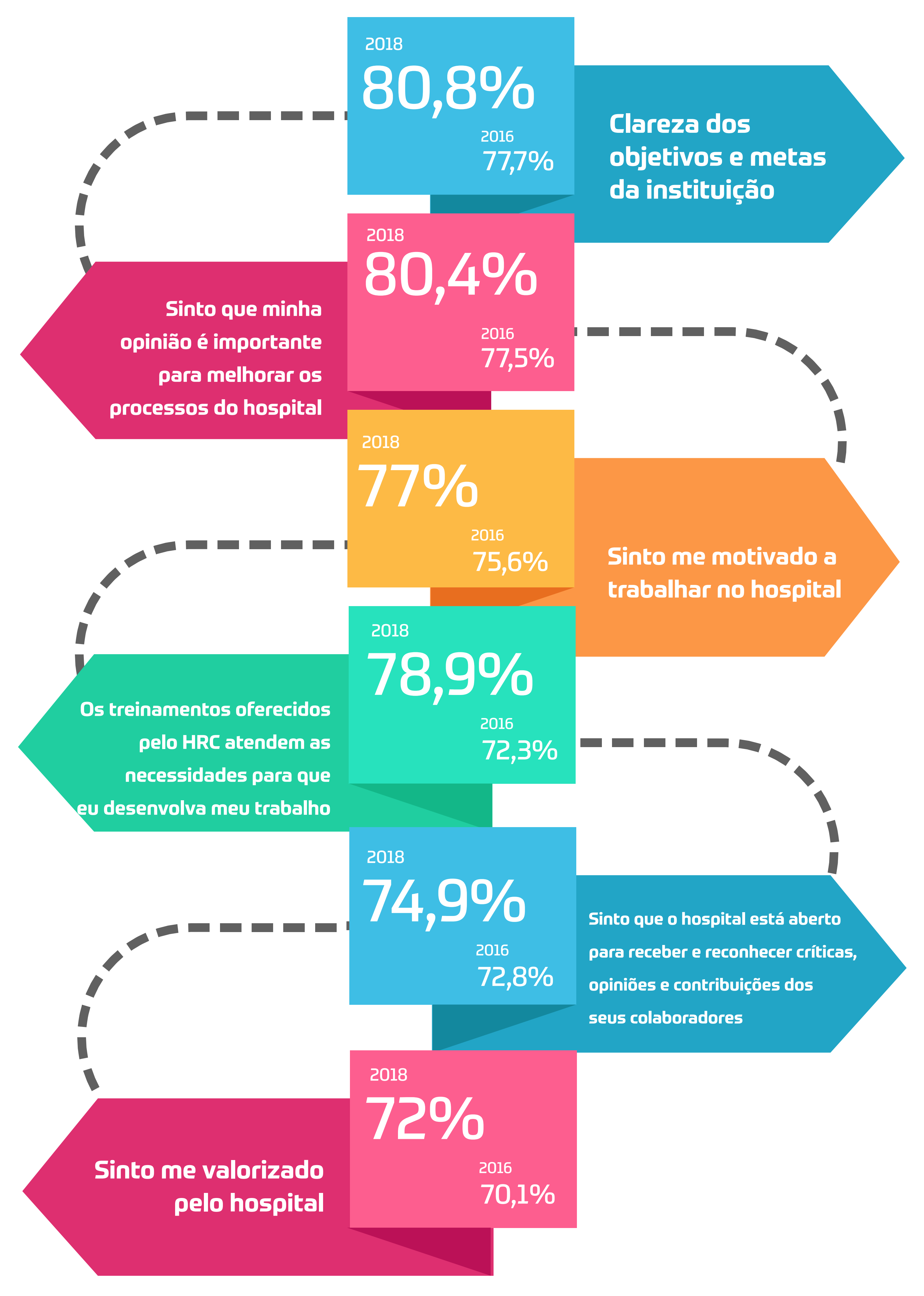

\section{Conclusão}

Observou-se uma correlação do clima com a efetividade dos treinamentos, quanto melhor o clima da instituição maior a probabilidade da transferência dos CHA, contribuindo assim para a melhoria da qualidade e segurança da assistência prestada. 